УДК: 72.033 .5

ББК: 85.11

A43

DOI: $10.18688 /$ aa199-4-46

\title{
E. Pizzoli
}

\section{Palermo in the $14^{\text {th }}$ Century: Between Latins and Catalans}

During the Middle Ages the art of Sicily was characterized by a great plurality of artistic influences and styles due to the position of the island in the middle of the Mediterranean basin, which made it a border land where different cultures coexisted influencing each other. The Norman dominion created a unique example of cultural syncretism uniting Norman architecture, Byzantine decoration and Arabic art. During this period Palermo becomes one of the biggest cities in the Western Europe [30, p. 117 ${ }^{1}$.

Under the dominion of Frederick II (1194-1250) the capital lost its importance and the population declined drastically [46, p. 114]. The artistic and architectural activity was strictly reduced. The only constructions of this period in the city were the completion of the cathedral started in 1169 by Gualtiero Offamilio ( $\dagger 1190)$ [39, pp. 133-134; 40, pp. 15-27], and the building of the church of S. Francesco, started in 1255 and completed in 1302 [43, pp. 37, 51-58].

After the fall of the Swabian dominion, from 1266, Sicily was subjected to the power of Charles I of Anjou (1224-1285), who imposed a strict fiscal policy for financing his wars outside the island [44, pp. 167-168]. During his reign he never trusted the Sicilians and all the key roles in the government were given to French nobles or jurists or other persons coming from his dominions [44, pp. 165-167].

These conditions and this treatment of the population prepared the revolt that exploded at the Vespers of the Easter Monday of 1282. On that day a French soldier tried to abuse a married Sicilian woman and was killed by her husband; when the comrades wanted to intervene to revenge him, the popular rebellion arose with the cry "moranu li Francisi" - Death to the French - exterminating all the French in the city [44, p. 280-281].

The rebels wanted the papal protection and a king with Swabian heritage, but Martin IV (1281-1285), a French pope, refused to help them imposing the Interdict to the island [44, p. 287]. Then the Sicilians offered the crown of the Sicilian kingdom to Peter III of Aragon (1240-1285), the husband of Constance (1249-1302), the daughter of Manfred of Sicily (1232-1266) [44, p. 295].

The new king had no real power, and the baronial families, both local and from Iberic peninsula, ruled the island originating a division between Latin and Catalan fractions ${ }^{2}$. These

For a history of the art of the Normans dominion see $[1 ; 30 ; 46]$.

For the fights between these families and the weakness of the Aragonese power see $[2 ; 34 ; 35]$. 
families showed their power through the construction of their residences, new ecclesiastical buildings and family chapels $[19 ; 25 ; 38 ; 39]$.

In this period Palermo, subjected to Chiaramonte family ${ }^{3}$, witnessed the manifestations of the baronial power of the Latin fraction, resulting in the construction of new palaces, chapels and churches. These buildings were decorated with the inlayed stone technique, or tarsia, inherited from the Normans and probably conveying some political message against the Catalans.

The origin of this type of decoration is not certain, the opinions of the art historians divide into two theories. The first follows the line traced by Émile Bertaux in his work, Lart dans l'Italie Méridionale, hypothesizing the origins of this decorative pattern in the Arabic world [5, pp. 620-622] $]^{4}$. The second, supported by monumental evidence, suggests that the lithic tarsia originated in Campania, in particular, Salerno, after the Norman conquest in 1076 [7; 21].

After the conquest Robert Guiscard (1015-1085) and the Archbishop Alfanus ( $\dagger 1085)$ financed the construction of the new cathedral consecrated in 1084 [26, p. 43]. The cathedral's four-sided portico presents blocks of different color and the insertion of round decorative patterns enriched with tarsia. The use of this kind of decoration could have been influenced by Montecassino Abbey rebuilt by Desiderius (1027-1087) and consecrated in 1071. Alfanus, the former monk of this abbey, was there when the new monastery was consecrated. The new structure could have had this kind of decoration [7, p. 19].

Tarsia is also present in other buildings of Salerno, such as the loggia in S. Maria della Pietà. The church is first mentioned in 1219 , but the arches with the stone inlay are dated to the Romanesque period [27, pp. 49-52]. The black stone is inserted, with a geometric design, in the stringcourse and in the cornice of the arches.

Another example is the Fruscione palace consisting of several buildings probably united at the end of the $13^{\text {th }}-$ beginning of the $14^{\text {th }}$ century [17, pp. 258-260; 18]. The $12^{\text {th }}$ century part preserved in the western facade is characterized by the remains of windows with the same decoration as in the loggia of S. Maria della Pietà [18, p. 31].

Yet the most important example in Salerno are the remains of Castel Terracena, the first residence of Robert Guiscard, already completed in 1086 [26, p. 19]. It has the same decoration of the windows as the cathedral, and also some new elements, such as the cornices that underline the arches of the windows and a decorative band with geometric design.

Following this theory, the stone inlay comes to Sicily with the Normans. One of the oldest examples of this pattern in the island is in the Church of Ss. Pietro e Paolo d'Agrò, dated to $1117[7$, p. 10].

In Sicily this decoration becomes more elaborated than in Campania, which is evident in the bell tower of the Martorana started in 1143 [30, pp. 75-76], in the apses and the cloister of Monreale cathedral, built between 1172 and 1189 [28], and in Palermo cathedral started under Gualtiero Offamilio ( $\dagger 1190$ ) in 1169 , consecrated in 1185 , and finished in the $15^{\text {th }}$ century $[3 ; 16 ; 39 ; 40]$. In these buildings the stone inlay covers not only the architectural details but also the entire walls. Some vegetal and heraldic motifs were also introduced in this decoration in Sicily. 
Probably the long construction of the cathedral was the reason for maintaining this decorative pattern in Palermo until the $14^{\text {th }}$ century ${ }^{5}$. In fact, the cathedral façade was completed during the $14^{\text {th }}$ century $[16 ; 39]$ and the South portal was built in the $15^{\text {th }}$ century $[3 ; 40]$.

As mentioned before, in the $14^{\text {th }}$ century the stone inlay becomes a sort of political message used by the Latin families in opposition to the Catalans.

The first example is the Chiaramonte palace (Ill. 94), also referred to in the documents as Steri, derived from hosterium Magnum [39, p. 55]. The building is located near the Cala, the ancient harbor, in a terrain that Giovanni I Chiaramonte ( $\dagger$ 1339), count of Modica, bought from fra' Cirino, prior of S. Mary in Ustica, in 1306 [39, p. 39]. The construction of the palace is dated to the 1320-1330s [41, pp. 391-393] .

The structure is a quadrangular block with a central court with a porch characterized by eight pointed arches, two on each side, sustained by eight round pillars. In the beginning the palace had only two storeys, the ground floor and the noble floor.

The second phase of the palace construction was probably due to Manfredi III ( $\dagger 1391$ ). In 1377-1380 he decided to decorate with paintings the Sala Magna ${ }^{7}$, the large room in the noble floor. He commissioned the paintings to three painters: Cecco from Naro, Simone from Corleone and Pellegrino Darenu [6, p. 37]. During this period the construction of the second floor was started, yet it remained incomplete. Only an open gallery and the Sala delle Capriate at the top of the building were constructed [29, pp. 42-43].

The exterior of the Steri resembles a solid cubic tower. The building represents the passage from a donjon to a civic residence. The ground floor has an austere character with embrasures intended to give light to the interior. The entrances are posed on the South façade, as well as on the East and North side.

The noble floor, divided from the ground floor by a stringcourse and decorated with diamond-shaped blocks, is less austere. On all sides it is enriched with double arched and triple arched windows linked to each other with a decorative molding. The distribution of the windows underlines the importance of the interiors: the triple arched windows give light to the Sala Magna, posed on the North side of the palace, and the double arched windows give light to other rooms. The palatine chapel in the North side of the building is recognizable from the outside thanks to a small oculus.

The openings and the molding are decorated with the stone tarsia (Fig. 1), which is used to underline with a geometric design the pointed arches of the windows and the cornices of the oculi. In the molding the black stone emphasizes the sculpted vegetal design.

The triple arched and double arched windows on the internal porch that give light to the Sala Magna are realized with a different technique. These openings present sculpted cornices and oculi decorated with an intricated tracery without the use of tarsia. The cornices present a chevron decoration used in a radial and perpendicular pattern.

The Chiaramonte palace became an example for other families. We know from the local chronicles that Matteo Sclafani (1280/81-1354), brother-in-law of Manfredi I Chiaramonte

For all phases of the cathedral construction see $[4 ; 13]$.

For the history of the palace and its phases see $[21 ; 29 ; 31 ; 39]$.

For the paintings see $[6 ; 8 ; 10 ; 11 ; 12 ; 21]$. 


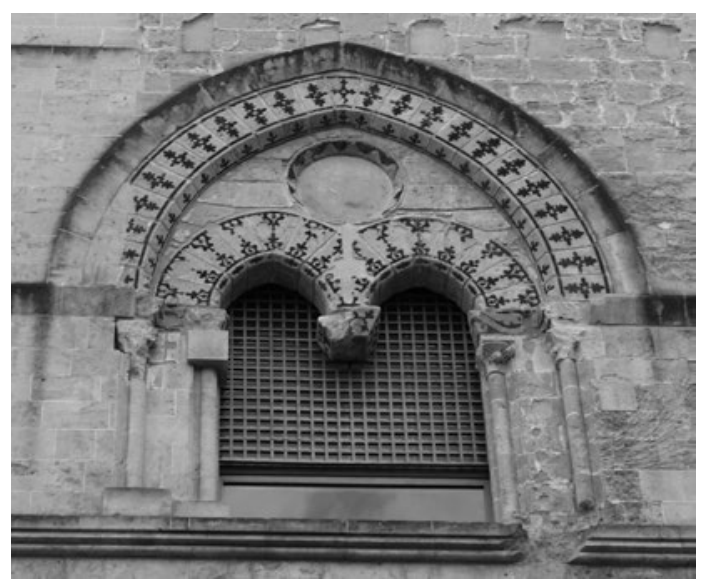

Fig. 1. Window. $14^{\text {th }}$ century. Chiaramonte palace. Palermo. Photo by E. Pizzoli

$(\dagger 1321)$, wanted to build, in a year, a residence bigger than the Steri [37, pp. 113-114]. The result of this challenge was the Sclafani palace (Ill. 95) built near the Normans palace in the Cassaro quarter, in order to underline the power of the owner. Constructed in 1330, the structure has a square plan with a central court with a porch on the ground floor and an open gallery on the noble floor and an atticus. The palace's façade is 50 meters long, ten meters more than that of the Steri, and is decorated with round interlaced arches. The ground floor, modified in the late $19^{\text {th }}$ century, when the palace became a Carabinieri station, preserves the original entrance characterized by a pointed arch with a cornice decorated with palmette (Fig. 2). On the top there is an edicula with the coat of arms of Palermo, of the Kingdom of Sicily, of the Aragon family and the Sclafani one, composed of two cranes; on the edicula's top there is a marble statue of an eagle made by Bonaiuto Pisano [37, p. 118].

Like in the Steri, the noble floor is enriched by a series of mullioned windows, with oculi on their top, included in interlaced round arches. Arches, windows and oculi are decorated with stone tarsia. It is used here in a way different from that in Chiaramonte palace. In fact, the black stone doesn't have a geometric or vegetal design but it is used in blocks alternating in the cornices with the palace's limestone blocks.

The black stone also appears in other palaces and structures preserved in the city. Some of these buildings present the patterns used in Sclafani palace, others use the Chiaramonte 
palace ones. An example discovered in the 1980s [33, pp. 152-153] is the Cefalà palace (Fig. 3) which belonged to the Opezzinga family in the $14^{\text {th }}$ century [38, p. 323]. The palace, located in via Alloro, the main street of the Kalsa quarter, is now included in other buildings. Its front side is preserved. It features the remains of triple arched and double arched windows, like Sclafani palace, with lava stone blocks alternated with the limestone blocks. This example also includes the sculpted chevrons as seen in the internal windows of the Steri.

Other two buildings show a different use of the black stone. The first is the double arched window, of an unknown palace, included in the $16^{\text {th }}$-century residence of Castrone di Santa Ninfa family [38, pp. 32-33; 39, p. 117]. In this case the tarsia is used to trace a series of interlaced arches. This design is also used in the anonymous palace in Alessandro Paternostro street rediscovered in recent years [20]. The last private building is the Santamarina palace, built in the $14^{\text {th }}$ century by the Crispo family on the ancient walls of the city. The façade is characterized by alternated black and limestone strips. This is a uniqum in Palermo with this kind of decoration [38, pp. 119-120; 39, pp. 112-113] (Fig. 4).

The stone tarsia was also inserted in some Norman defensive buildings included in the $14^{\text {th }}$ century in new constructions. The first example is found in the tower of the $17^{\text {th }}$ century Federico family palace, where a double arched window with a geometric decoration reminding the Steri was opened in the $14^{\text {th }}$ century $[25$, pp. $20-22$; 38 , pp. $48-50$;

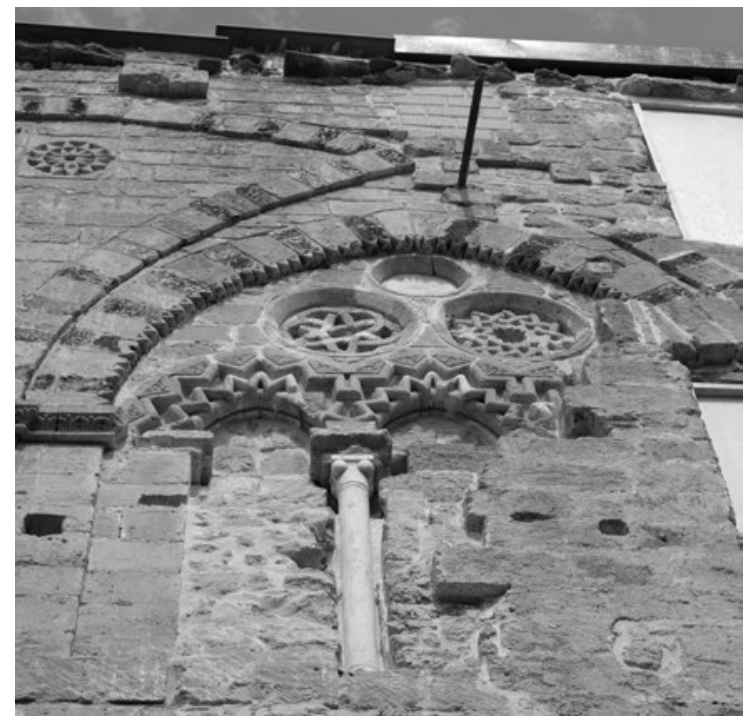

Fig. 3. Window. $14^{\text {th }}$ century. Cefalà palace. Palermo. Photo by E. Pizzoli

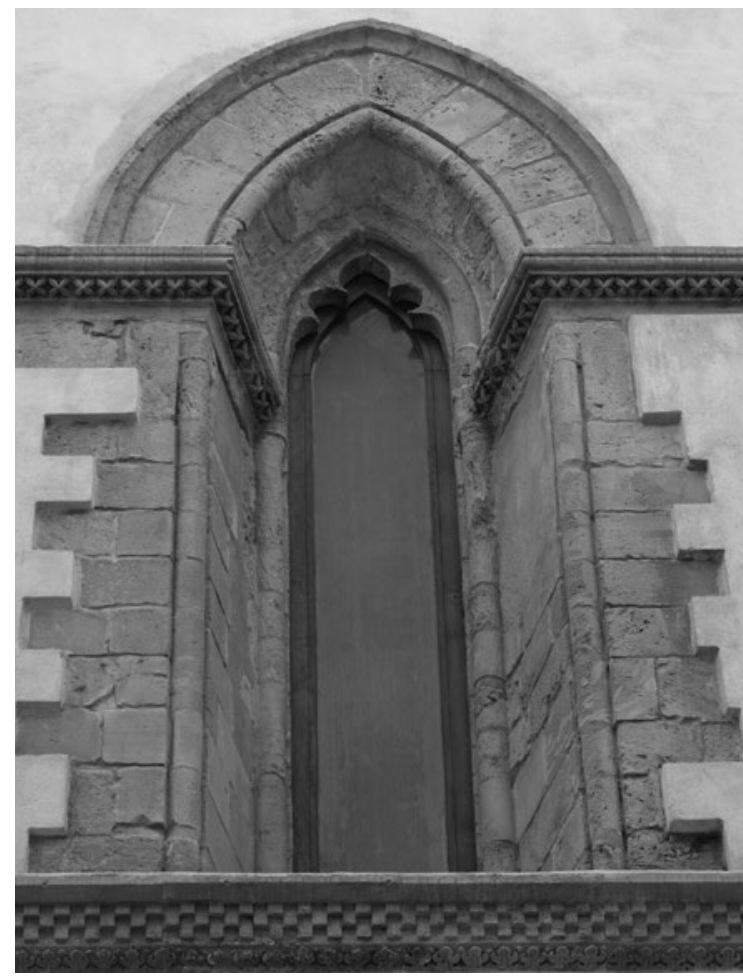

Fig. 5. Window. $14^{\text {th }}$ century. S. Antonio allo Steri. Palermo. Photo by E. Pizzoli 


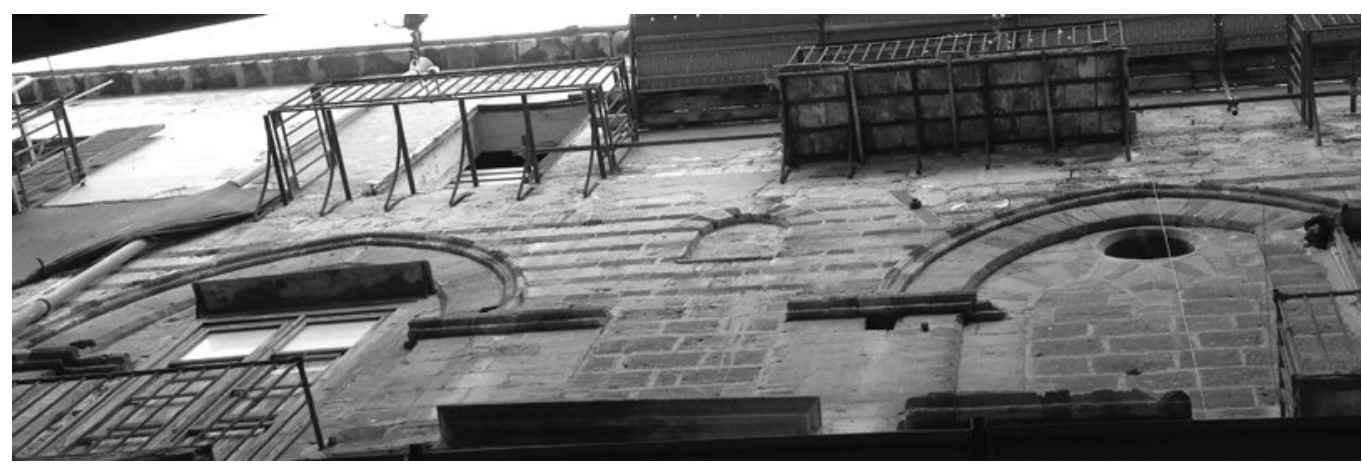

Fig. 4. Detail of the façade. $14^{\text {th }}$ century. Santamarina palace. Palermo. Photo by E. Pizzoli

39, pp. 108-111]. The second example is the belltower of S. Nicolò in Albergaria, modified with the insertion of the black stone in the windows [25, pp. 19-20; 39, pp. 101-107].

The baronial families also used the inlay decoration in the religious buildings, such as the façade of S. Agostino church built at the end of the $13^{\text {th }}$ century and completed in the first half of the $14^{\text {th }}$ century. The decoration similar to the Steri enriches the portal [39, pp. 140-146]. On the sides there appear the shields of Chiaramonte and Sclafani families made with the black stone.

A very particular use of the tarsia and a unique case in an interior is found in Calvello chapel in S. Francesco basilica [25, pp. 76-77; 39, pp. 121-122]. Built in the first half of the $14^{\text {th }}$ century by Giovanni Calvello, the chapel with a square plan and an apse is covered with a ribbed vault. The structure presents some elements derived from the Norman tradition, such as columns at the base of the apse arch. The volcanic stone is used to decorate the interior of the chapel in a rich sequence of geometric and floral design which covers all the structural elements. Even the family's coat of arms is used as a decorative pattern and is repeated in an obsessive way.

Only in the second half of the $14^{\text {th }}$ century a new type of architectural language appeared in the buildings. The first example is S. Antonio allo Steri [25, pp. 51-52; 39, pp. 153-156]. The inscription on the façade windows says that this small church was built by a Manfredi, probably Manfredi III Chiaramonte, at the time of the works that he commissioned in the Steri [15, p. 7]. The chapel is located near the great residence of the Counts of Modica. It is a single hall covered by two ribbed vaults with bosses and polygonal ribbed vault apse, which is rare for the architecture of Palermo, where wooden trusses were more common.

On the outside, the building is an austere block characterized by three levels separated by two stringcourses. The first one is decorated with cubic denticles and the second with diamond pattern. On the façade there are two windows in white limestone and a marble portal, all decorated with the Chiaramonte family emblem.

The difference from the nearby palace is clear. It confirms the attribution of the building to Manfredi III. In fact, the chapel has more gothic details: the high ribbed vaults sustained by beam pillars, which give to the structure a more vertical movement; the high lancet windows; the armaria decorated with a gothic trefoil tracery and the ribbed umbrella-type apse. 
As in Calvello chapel, the family emblem is also used here, but in a different way, as a decorative pattern: the tracery of the lancet windows reminds of the five mounts of the Chiaramonte coat of arm (Fig. 5).

The second example is another commission of Manfredi III, the abbey of S. Maria in Baida. The monastery was built after the destruction in 1370 of the fortress Castellaccio of Monreale, property of S. Martino alle Scale abbey. The castle was attacked by Manfredi suspecting that the monks wanted to give it to the Catalans [14, p. 5]. After the destruction the bishop of Monreale and the pope Urban V (1362-1370) tried to resolve the dispute between the Monastery and Manfredi III. The Count refused to rebuild the fortress. In 1371 he proposed to donate the fief of Baida to S. Martino alle Scale and "...Sancatee Marice de Angelis fundare..." [32, p. 281]. The construction probably started in 1388, after the papal approval of 1385 [32, p. 252].

The uncompleted abbey is located 5 kilometers outside Palermo, on the top of a promontory at 167 meters on the sea level, located between the Monte Cuccio and the Conca d'Oro. The complex preserves the medieval phase: the church, some parts of the cloister, the chapter house front and two windows of the dormitory. The façade is characterized by a mullioned window, with Chiaramonte coat of arms, included in a hood mould sustained by two semicolumns. The front of the church is closed by a porch with three pointed arches, probably added in the $15^{\text {th }}$ century ${ }^{8}$. The hood mould design, like the lancet windows of S. Antonio allo Steri, reminds the family's heraldic emblem.

The interior is a single hall church with separated choir. Originally the structure was covered by wooden trusses. It was modified in the $18^{\text {th }}$ century, between 1755 and 1756 , when the architect Orazio Furetto (1714-1785) remade the interior covering the medieval walls and building the actual barrel vault [14, pp. 37-38]. The choir, separated by a triumphal arch and restored in the 1980s, is covered by ribbed vault, with boss sustained by corbels.

The architectural decoration of the uncompleted cloister shows a mixture of some Norman and Catalan gothic elements. The only part of the cloister completed under Manfredi III are the six bays in the south and east galleries. All the bays are covered with ribbed vaults with bosses decorated by the coat of arms of the Chiaramonte, of the Aragonese, and of Palermo.

The Norman elements are also present in the marble capitals of the twin columns. Ten of the eleven couples are $14^{\text {th }}$ century copies of the capitals of Monreale cloister ${ }^{9}$. The decision to copy the Monreale capitals was probably due to Manfredi III who controlled almost the entire island by that time and felt as a new king of Norman descent ${ }^{10}$.

The Catalan gothic influence manifested in the ribbed vaults of the church and of the cloister is also visible in the front of the Chapter house where the left window preserves an intricate tracery composed by three trefoil heads and five quatrefoils (Ill. 96). The sculpted details are made in a different way: the capitals and the corbels are rendered with a metallic carving.

\footnotetext{
$8 \quad$ Spatrisano and Caracciolo hypothesize that the porch was made during the works finished in 1511 by the archbishop Giovanni Paternò, but the portal with his coat of arm doesn't fit in the structure [see 39, p. $158 ; 14$, p. 11].

$9 \quad$ For the capitals see $[9 ; 10 ; 23 ; 24 ; 28$, pp. 228-229].

10 The family's original name was Clermont, it came to South Italy from Normandy following the Great Count Roger (1040-1101) [39, p. 271].
} 
The churches of S. Antonio allo Steri and S. Maria degli Angeli in Baida are probably the first examples of Catalan gothic influence in the city of Palermo. After the fall of Chiaramonte in 1392 and the normalization of the city under the dominion of the Aragonese kings other masterpieces were produced, such as the palaces Abatelli and Ajutamicristo, made by Matteo Carnilivari (active in 1487-1493), and the church of S. Maria della Catena, all built at the end of the $15^{\text {th }}$ century - beginning of the $16^{\text {th }}$ century.

These examples show how Palermo and Sicily, even in the end of the Middle Ages, remained a border land where local traditions and external influences were mixed into a new local language.

\section{References}

1. Abbate F. Storia dell'arte nell'Italia meridionale, vol. 1. Rome, Donzelli Editore Publ., 1997. 297 p. (in Italian).

2. Backman C. R. Declino e caduta della Sicilia medievale. Politica, religione ed economia nel regno di Federico III d'Aragona Rex Sicilice (1296-1337). Palermo, Officina di Studi Medievali Publ., 2007. 400 p. (in Italian).

3. Bellafiore G. Architettura in Sicilia (1415-1535). Palermo, Italia Nostra Publ., 1984. 331 p. (in Italian).

4. Bellafiore G. La cattedrale di Palermo. Palermo, Flaccovio Publ., 1999. 155 p. (in Italian).

5. Bertaux E. L'art dans l'Italie méridionale, vol. 1. Paris, Albert Fontemoing Publ., 1904. 1003 p. (in French).

6. Bologna F. Il soffitto della Sala Magna allo Steri di Palermo e la cultura feudale siciliana nell'autunno del Medioevo. Palermo, Flaccovio Publ., 1975. 342 p. (in Italian).

7. Bottari S. I rapporti tra l'architettura siciliana e quella campana del medioevo. Palladio, 1955, vol. 5, pp. 7-25 (in Italian).

8. Buttà L. Frammenti di cultura napoletana post-giottesca nella Sicilia chiaromontana: tappe di un viaggio. El Trecento en obres. Art de Catalunya $i$ art d'Europa al segle XIV. Barcelona, Publicacions i Edicions de la Universitat de Barcelona Publ., 2009, pp. 161-184 (in Italian).

9. Buttà L. Il chiostro di Manfredi: politica e raccomandazione dell'anima in Santa Maria degli Angeli di Baida. Ricerche di storia dell'arte, 2010, vol. 3, pp. 83-94 (in Italian).

10. Buttà L. Manfredi Chiaromonte e le arti: committenza artistica e egemonia politica in Sicilia alla fine del Trecento. L'immagine come messaggio. I significati dell'opera d'arte e la comunicazione iconica. Caltanissetta, Edizioni Lussografica Publ., 2012, pp. 37-70 (in Italian).

11. Buttà L. Storie per governare: iconografia giuridica e del potere nel soffitto dipinto della Sala Magna del palazzo Chiaromonte Steri di Palermo. Narrazione, Exempla, Retorica: studi sull'iconografia dei soffitti dipinti nel Medioevo Mediterraneo. Palermo, Edizioni Caracol Publ., 2013, pp. 69-126 (in Italian).

12. Buttà L. La struttura, l'ordito e le sue fonti in relazione all'area mediterranea. Lo Steri dei Chiaromonte a Palermo. Bagheria-Palermo, Plumelia Edizioni Publ., 2015, pp. 117-134 (in Italian).

13. Calamia F.; Catalano A. La cattedrale di Palermo: otto secoli di vicende architettoniche. Palermo, Epos Publ., 1981. 224 p. (in Italian).

14. Caracciolo E. La chiesa e il convento di Baida presso Palermo. Palermo, Archivio Storico Siciliano Publ., 1938. 40 p. (in Italian).

15. Catalano A.; Conti C.; Lenzo M. C.; Musumeci R. Il restauro della chiesa di Sant'Antonio Abate allo Steri. Kalós, 2012, vol. 3, pp. 6-9 (in Italian).

16. Ciotta G. La facciata occidentale. Vicende edilizie e caratteri figurali. La cattedrale di Palermo. Palermo, Sellerio Publ., 1993, pp. 157-164 (in Italian).

17. Corolla A. Lettura stratigrafica degli elevati di Palazzo Fruscione (Salerno). Medioevo letto, scavato, rivalutato. Borgo S. Lorenzo, All’Insegna del Giglio Publ., 2012, pp. 255-266 (in Italian).

18. Corolla A. Architettura residenziale nella Salerno normanna: l'esempio di Palazzo Fruscione. Indagini sui centri dell'Italia meridionale e insulare (sec. XI-XV). Campania, Basilicata, Puglia, Calabria, Sicilia e Sardegna; atti del V convegno nazionale di studi (Orte, 15-16 marzo 2013). Roma, Edizioni Kappa Publ., 2014, pp. 27-39 (in Italian).

19. De Angelis Ricciotti D. Cappelle trecentesce e chiostro "piccolo" nel complesso di S. Francesco D’Assisi. Palermo e il Gotico. Palermo, Edizioni Caracol Publ., 2007, pp. 51-58 (in Italian). 
20. Fatta G.; Li Castri M.; Alcuri G.; Famoso M. Emerge dal buio dei secoli un affascinante brano d'architettura medievale. Kalós, 2012, vol. 1, pp. 18-23 (in Italian).

21. Gabrici E.; Levi E. Lo Steri di Palermo e le sue pitture. Milano; Roma, Edizioni Bestetti e Tumminelli Publ., 1985. 150 p. (in Italian).

22. Gambardella A. Le tarsie murarie in epoca federiciana. Cultura artistica, città e architettura nellétà federiciana. Roma, De Luca Publ., 2000, pp. 47-62 (in Italian).

23. Guttilla M. Nel segno dei lapicidi: figurazioni simboliche e restauri nel chiostro di Baida. Palermo, Quaderni dell'Archivio Fotografico delle Arti Minori in Sicilia, 1985. 127 p. (in Italian).

24. Guttilla M. Il chiostro del convento benedettino di Baida. Arte in Sicilia: Annali della Facoltà di Lettere e Filosofia dell'Università di Palermo: Studi e ricerche, 1986, vol. 11, pp. 101-113 (in Italian).

25. Inzerillo L. Il gotico chiaramontano, aragonese e catalano nella Sicilia Occidentale, monofore bifore trifore e cappelle interne. Palermo, Edizioni Caracol Publ., 2008. 193 p. (in Italian).

26. Kalby L. G. Tarsie murarie nella Salerno medioevale. Salerno, Laveglia Publ., 1970. 45 p. (in Italian).

27. Kalby L. G. Tarsie e archi intrecciati nel romanico meridionale. Salerno, Testaferrata Publ., 1971. 237 p. (in Italian).

28. Krönig W. Il duomo di Monreale. Palermo, Flaccovio Publ., 1965. 321 p. (in Italian).

29. Lima A. I. (ed.). Lo Steri dei Chiaromonte a Palermo. Bagheria; Palermo, Plumelia Edizioni Publ., 2015. 523 p. (in Italian).

30. Maurici F. Palermo Normanna. Vicende urbanistiche d’una città imperiale (1072-1194). Palermo, Kalós Publ., 2016. 192 p. (in Italian).

31. Nobile M. R. Lo Steri di Palermo tra XIV e XVI secolo. Palermo, Edizioni Caracol Publ., 2015. 94 p. (in Italian).

32. Pecorella G. Per la storia della contrada e del convento di Baida. Documenti e illustrazioni. Archivio Storico Siciliano, 1967, vol. 17, pp. 247-308 (in Italian).

33. Prescia R. Restauri a Palermo, architettura e città come stratificazione. Palermo, Kalós Edizioni d'Arte Publ., 2012. 212 p. (in Italian).

34. Sardina P. Palermo e i Chiaromonte splendore e tramonto di una signoria. Caltanissetta, Salvatore Sciascia Editodre Publ., 2003. 528 p. (in Italian).

35. Sardina P. Ceti dirigenti, società ed economia del quartiere Kalsa ni secoli XIV e XV. Il quartiere della Kalsa a Palermo. Palermo, Regione Siciliana Assessorato dei Beni Culturali e dell'Identità Siciliana Publ., 2013, pp. 15-27 (in Italian).

36. Scarlata M. I Chiaromonte a Palermo nel XIV secolo: uso della città e gestione economica. Bullettino dell'Istituto Storico Italiano per il Medio Evo, 1984, vol. 90, pp. 303-329 (in Italian).

37. Scibilia F. Palazzo Sclafani. Palermo e il gotico. Palermo, Edizioni Caracol Publ., 2007, pp. 113-118 (in Italian).

38. Sommariva G. Palazzi Nobiliari di Palermo. Palermo, Flaccovio Publ., 2004. 331 p. (in Italian).

39. Spatrisano G. Lo Steri di Palermo e l'architettura siciliana del Trecento. Palermo, Flaccovio Publ., 1972. 299 p. (in Italian).

40. Sutera D. Interventi nella cattedrale di Palermo tra XIV e XV secolo. Palermo e il Gotico. Palermo, Edizioni Caracol Publ., 2007, pp. 107-112 (in Italian).

41. Rizzuto F. Lo Steri e i palazzi dei Chiaromonte a Palermo. Enrico Mauceri (1869-1966), storico dellarte tra connoisseurship e conservazione. Palermo, Flaccovio Publ., 2009, pp. 389-394 (in Italian).

42. Rosi G. Il duomo di Amalfi. Le Arti, 1942, vol. 5, pp. 348-349 (in Italian).

43. Rotolo F. La Basilica di San Francesco d'Assisi e le sue cappelle. Bagheria, Provincia di Sicilia dei Frati Minori Conventuale "Ss. Agata e Lucia" Publ., 2010. 454 p. (in Italian).

44. Runciman S. I vespri siciliani. Bari, Dedalo Publ., 1986. 408 p. (in Italian).

45. Toesca P. Il Medioevo. Torino, Utet Publ., 1927. 1200 p. (in Italian).

46. Zoric V. Palermo. Enciclopedia dell'Arte Medievale, vol. 9. Roma, Istituto della Enciclopedia Italiana Publ., 1998, pp. 108-125 (in Italian).

Title. Palermo in the $14^{\text {th }}$ Century: Between Latins and Catalans.

Author. Enrico Pizzoli - Ph. D. student. Sapienza Univeristy of Rome, Piazzale Aldo Moro 5, 00185 Rome Italy. enrico.pizzoli@uniroma1.it

Abstract. During the Middle Ages Sicily is characterized by a great plurality of influences due to the position of the island, between the West and the East, in the Mediterranean basin making it a border land where 
different cultures coexisted influencing each other. The Norman dominion created a unique kind of cultural syncretism that was typical of this region until the $15^{\text {th }}$ century. After the Sicilian Vespers (1282), when the island revolted against the Angevin dominion, the crown of the Sicilian kingdom was offered to Peter III of Aragon (1273/74-1337). The new king had no real power, and the baronial families, divided in Latin and Catalan fractions, ruled the island. These families showed their power through the construction of their residences, new ecclesiastical buildings and family chapels.

In Palermo in the decoration of private palaces the use of Arabic stone inlay, or tarsia, becomes an expression of the Latin fraction. The stone tarsia was also used in religious buildings, such as the façade of S. Agostino church, built at the end of the $13^{\text {th }}$ century, or the Calvello chapel in S. Francesco built at the beginning of the $14^{\text {th }}$ century, both build by private commission. This kind of decoration during this period was probably used as a political message of the Latin families adversary to the Catalan, Iberian families that arrived to the island with the Aragon king.

Only in the second half of the $14^{\text {th }}$ century new architectural language appeared in buildings such as St. Antonio at Steri constructed by Manfredi III Chiaromonte ( $\dagger 1391)$, where the stone decoration was abandoned and new elements were used, such as the ribbed vaults and a rib-vaulted apse. Another Chiaramonte commission, St. Maria in Baida, shows the use of Catalan gothic motives in the architectural decoration.

The focus of this paper is to underline how the island in its condition of border land was subjected to the influence of other cultures which expanded its horizons in the arts and architecture.

Keywords: Palermo; Sicily; architecture; stone tarsia; private architecture; Chiaramonte; Gothic.

Название статьи. Палермо в XIV веке: между латинянами и каталонцами.

Сведения об авторе. Пиццоли Энрико - аспирант. Университет Сапиенца, Рим, Пьяццале Альдо Mopo, 5, 00185 Рим, Италия. enrico.pizzoli@uniroma1.it

Аннотация. В средневековой Сицилии наблюдается значительное разнообразие влияний, что связано с пограничным по отношению к западно- и восточнохристианскому миру положением острова в средиземноморском бассейне, делающим его ареной взаимодействия различных культур. В период правления норманнской династии возникла уникальная ситуация культурного синкретизма, сохранявшаяся в регионе до XV в. После Сицилийской вечерни (1282), когда население острова восстало против господства Анжуйского дома, корона Сицилийского королевства была передана Педро III Арагонскому (1273/74-1337). Новый король не обладал реальной властью, и островом правили представители местной знати, разделившиеся на фракции «латинян» и «каталонцев». Одним из способов демонстрации влияния знатных родов стало строительство резиденций и заказ новых церквей и семейных капелл. В Палермо «маркировкой» заказа фракции латинян стали инкрустации арабского типа из цветного камня, или tarsia, используемые в декоре частных палаццо. Tarsia использовались также и в религиозных сооружениях, связанных с частным заказом, например в декоре фасада церкви Сан-Агостино (конец ХІІІ в.) или капеллы Кальвелло в церкви Сан-Франческо (начало $\mathrm{XIV}$ в.). Использование такого типа декора в этот период можно рассматривать как проявление политического влияния знатных родов «латинской» фракции, враждебно настроенных по отношению к прибывшим на остров вслед за королём-арагонцем каталонским и иберийским семьям.

Только во второй половине XIV в. на Сицилии появляются элементы нового архитектурного языка. Так, например, в церкви Сант-Антонио в Стери, построенной Манфредом III Кьярамонте (ум. 1391) используются нервюрные своды в нефе и апсиде. В декоре церкви Санта-Мария-ин-Байда, возведённой также по заказу Кьярамонте, появляются элементы архитектурного декора, заимствованные из каталонской готики.

Главная задача статьи - показать, каким образом благодаря пограничному положению и влиянию различных традиций расширяются границы архитектурного и художественного языка в культуре Сицилии XIII-XIV вв.

Ключевые слова: Палермо; Сицилия; архитектура; инкрустации из камня; частный архитектурный заказ; Кьярамонте; готика. 


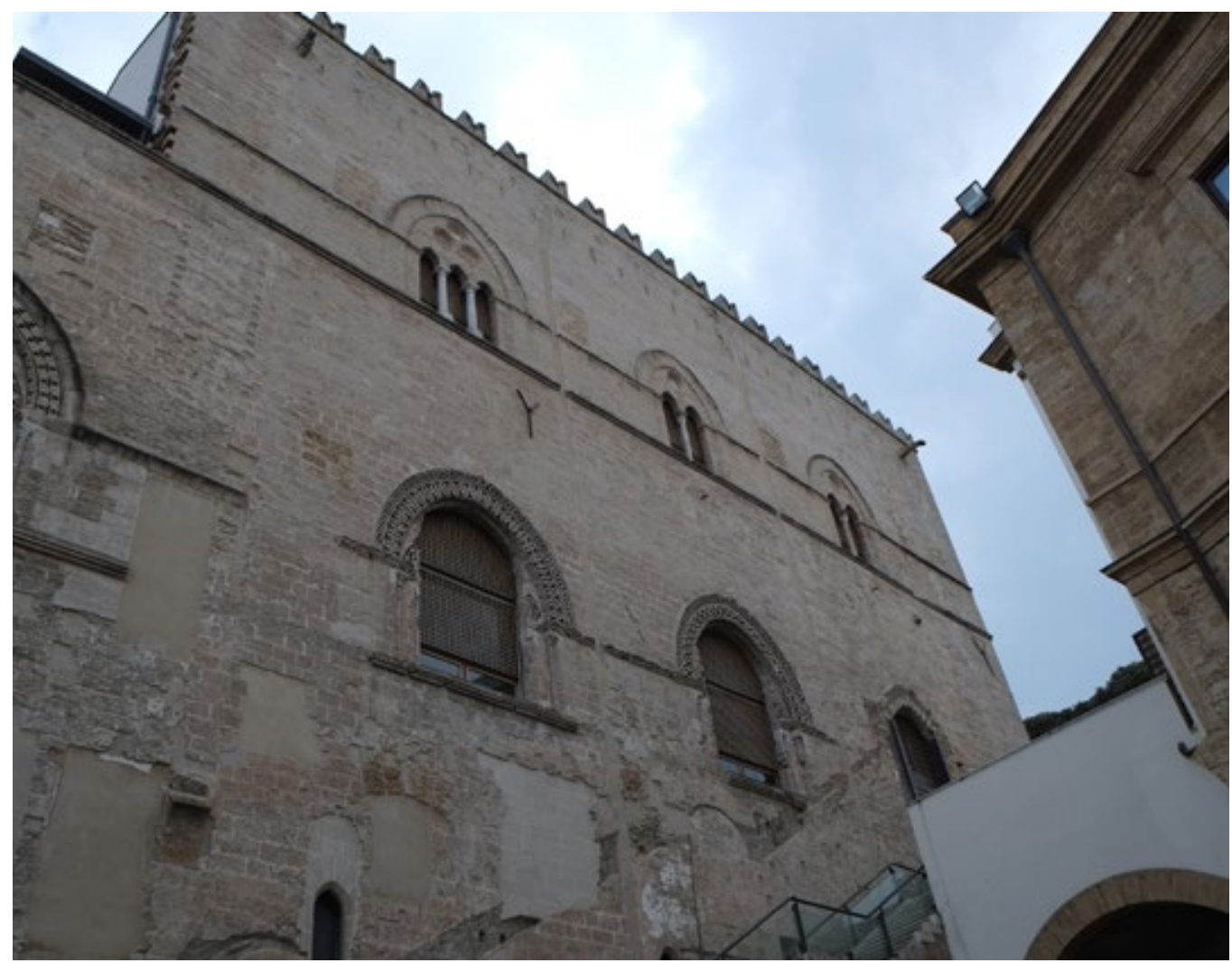

III. 94. Chiaramonte palace. $14^{\text {th }}$ century. Palermo. Photo by E. Pizzoli

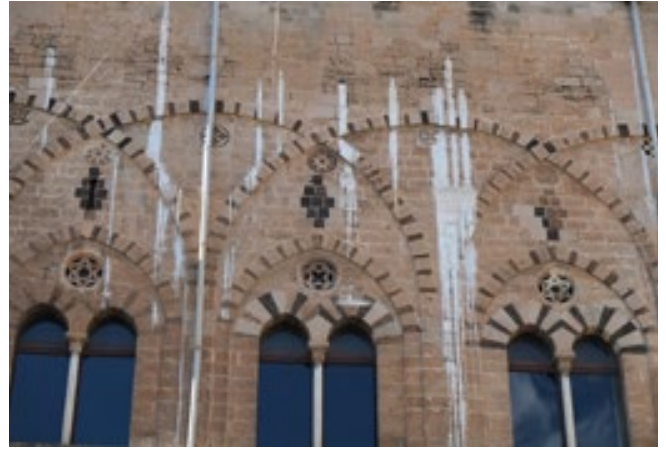

III. 95. Sclafani palace. Detail of the façade. $14^{\text {th }}$ century. Palermo. Photo by E. Pizzoli

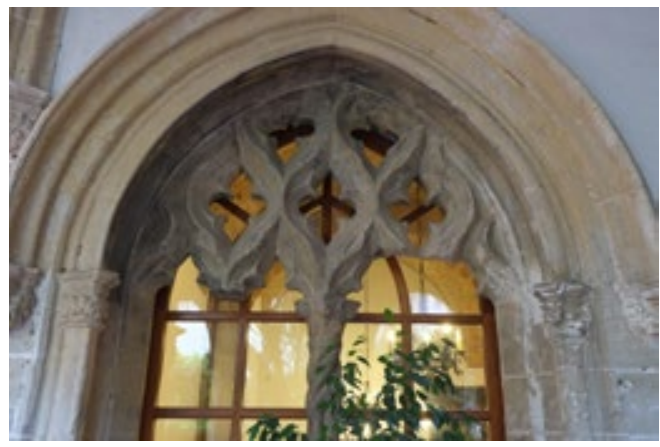

III. 96. S. Maria degli Angeli in Baida. Window of the Chapter House. $14^{\text {th }}$ century. Palermo.

Photo by E. Pizzoli 